\title{
Dexamethasone Treatment of Infants at Risk for Chronic Lung Disease: Surfactant Components and Inflammatory Parameters in Airway Specimens
}

\author{
M. A. KARI, K. O. RAIVIO, P. VENGE, AND M. HALLMAN \\ Children's Hospital, University of Helsinki, Helsinki, Finland [M.A.K., K.O.R.]; Department of \\ Clinical Chemistry, University Hospital Uppsala, Uppsala, Sweden [P.V.]; and Department of \\ Pediatrics, University of California, Invine, California 92717 [M.H.]
}

\begin{abstract}
The mechanisms explaining the beneficial effects of glucocorticoid in ventilator-dependent preterm infants are not known. In the present randomized trial, we evaluated the hypothesis that dexamethasone (DEX) treatment of small, preterm infants at risk for chronic lung disease favorably affects the surfactant system. Twenty-three ventilatordependent infants, with a mean \pm SD gestational age of 26 \pm 2 wk and a mean birth weight of $836 \pm 173 \mathrm{~g}$, received 1 wk of treatment with either DEX (dose $0.5 \mathrm{mg} / \mathrm{kg} / \mathrm{d}$ ) or placebo beginning at 2 wk of age. The airway specimens were analyzed for surfactant components, surface activity, surfactant inhibitors, and inflammatory mediators. The concentrations of these parameters in epithelial lining fluid were calculated using the urea method. DEX treatment decreased the concentration of nonsedimentable protein in epithelial lining fluid within $3 \mathrm{~d}(p<0.05)$. The nonsedimentable fraction of airway specimens decreased the surface activity of surfactant as a function of protein concentration. At a constant protein concentration, the protein from placebo-treated infants inhibited the surface activity of human surfactant in vitro more than protein from DEXtreated infants $(p<0.05)$. DEX transiently increased the
\end{abstract}

\section{ABSTRACT}

concentration of surfactant protein-A in epithelial lining fluid but had no effect on surface activity of the sedimentable surfactant complex or on concentrations of phosphatidylcholine, IL-1 $\beta$, lactoferrin, or myeloperoxidase. We conclude that the acute beneficial effect of DEX treatment in preterm ventilator-dependent infants may in part be mediated through a decrease in the concentration of nonsedimentable protein and a decrease in the capacity of this protein to inhibit surface activity. (Pediatr Res 36: 387-393, 1994)

AS, airway specimen

Abbreviations

CLD, chronic lung disease

DEX, dexamethasone

ELF, epithelial lining fluid

LF, lactoferrin

MPO, myeloperoxidase

PC, phosphatidylcholine

PL, placebo

SP-A, surfactant protein-A

SPC, disaturated phosphatidylcholine
Despite improved survival, many preterm infants fail to recover from the acute lung injury and develop CLD. In addition to immaturity, factors contributing to the development of CLD include barotrauma, oxygen toxicity, and inflammation $(1,2)$. The significance of the various suggested pathogenetic mechanisms is unclear.

DEX therapy decreases the requirement of respiratory support and improves pulmonary mechanics in ventilator-dependent preterm infants (3-6). In several controlled

Received September 13, 1993; accepted March 22, 1994.

Correspondence: Anneli Kari, M.D., Children's Hospital, University of Helsinki, Stenbäckinkatu 11, FIN-00290 Helsinki, Finland.

Supported by the Foundation of Pediatric Research, Finland, and Foundation for Maternal and Infant Care, Orange County, CA. trials on ventilator-dependent very-low-birth-weight infants, DEX therapy has improved the short-term pulmonary outcome, decreasing the duration of mechanical ventilation, but not the long-term outcome (7-11). Many potential mechanisms for the acute effect of DEX have been proposed. These include an increase in surfactant synthesis $(12,13)$ and in activity of antioxidant enzymes (14) shown after prenatal glucocorticoid therapy in fetal animals, and reduction of pulmonary edema, lung water, and alveolar epithelial permeability shown in preterm infants with CLD $(5,6,15)$. DEX may additionally decrease pulmonary inflammation, suggested by reduction of neutrophil recruitment into the lungs $(5,16)$, and decrease bronchoalveolar lavage fluid concentrations of 
elastase $(5,16,17)$. However, the precise mechanism of action of DEX in ventilator-dependent, small, preterm infants is not known.

We performed a randomized PL-controlled multicenter trial on very-low-birth-weight infants, who were ventilator and oxygen dependent at the age of $10 \mathrm{~d}$ (18). Within the context of the trial, our aim was to investigate whether administration of DEX was associated with changes in inflammatory indices, surfactant components, or surface activity in the ELF and whether any of these parameters correlated with the pulmonary outcome.

\section{METHODS}

Patients. The 23 infants studied were treated at the Children's Hospital, University of Helsinki, between January 1989 and March 1991. They participated in the randomized, multicenter study of DEX therapy in infants at risk for CLD and composed $56 \%$ of all infants participating in this study (18). AS were available from all infants who were recruited into the study at the Children's Hospital, University of Helsinki. The very-lowbirth-weight infants were eligible for the study if they were ventilator dependent at $10 \mathrm{~d}$ of age and had no major malformation, sepsis, or patent ductus arteriosus. After informed consent was obtained from the parents, infants were randomly allocated to receive a $7-d$ course of either DEX sodium phosphate (Oradexon, Organon, Oss, The Netherlands) or PL. Infants in the DEX group received $0.5 \mathrm{mg} / \mathrm{kg} / \mathrm{d}$ DEX i.v. divided into two doses and those in the PL group received $0.9 \%$ saline. The study design was approved by the ethical committee of the hospital.

All infants required ventilatory support from birth. For all infants, supplemental oxygen and mechanical ventilation were adjusted to maintain arterial $\mathrm{Po}_{2}$ between 6.5 and $9.1 \mathrm{kPa}(50-70 \mathrm{~mm} \mathrm{Hg})$ or oxygen saturation of $\mathrm{Hb}$ between 88 and $92 \%$ and arterial or capillary $\mathrm{PCO}_{2}$ between 5.8 and $7.8 \mathrm{kPa}(45-60 \mathrm{~mm} \mathrm{Hg})$. Ventilatory support was provided with a pressure-limited ventilator $(\mathrm{Ba}-$ by-Bird, Bird Corp., Palm Springs, CA). Pulmonary outcome was evaluated at $28 \mathrm{~d}$ of age. CLD was defined as requirement of supplemental oxygen at $28 \mathrm{~d}$.

Collection of the AS. Tracheal aspirates of the intubated infants were obtained 1 to $2 \mathrm{~d}$ before the trial medication was started and daily during the 7 -d treatment period at times when suctioning was deemed necessary by the nursing staff. Before suctioning, $0.9 \%$ saline $(0.5$ to 1.0 $\mathrm{mL}$ ) was instilled into the intubation tube, and the infant was ventilated during a brief period. A catheter was then introduced into the airway distal to the tip of the endotracheal tube. Any fluid from the airways was suctioned into a mucus extractor (UnoPlast AS, Hundested, Denmark) within less than $20 \mathrm{~s}$ after the introduction of saline into the airways. After the procedure, 0.5 to $1.0 \mathrm{~mL}$ of saline was suctioned through the catheter into the Leukens trap to recover material retained in the side walls. Aspirates containing visible blood were not analyzed. The specimens were stored for a maximum of $12 \mathrm{~h}$ at $4^{\circ} \mathrm{C}$ and centrifuged at $150 \times g$ for $10 \mathrm{~min}$. The resulting supernatant, called AS, was recovered and stored at $-20^{\circ} \mathrm{C}$. A fraction $(0.2$ to $1.5 \mathrm{~mL})$ of the AS was further centrifuged at $40000 \times g$ for $120 \mathrm{~min}$, and the new high-speed supernatant was used for analysis of nonsedimentable protein and urea (19). The surfactant-rich lipidprotein complex, obtained as a pellet after the centrifugation at $40000 \times g$ for $120 \mathrm{~min}$, was washed once by suspension in water before resedimentation.

Measurements of proteins, phospholipids, and surface tension. SP-A was quantified in AS using a two-site immunoassay with two different MAb. The method has been described in detail previously $(20,21)$. Total nonsedimentable protein was measured by a modified Lowry method (22). Protein electrophoresis was performed in $10 \%$ SDS polyacrylamide gel with Mini-Protean II Cell (Bio-Rad Laboratories, Richmond, CA). Ratios of protein in AS to serum protein are presented for infants whose serum protein samples were collected within $24 \mathrm{~h}$ of the AS. The concentration of total PC and SPC in AS was measured as described (19).

The measurements of surface tension were performed at $37^{\circ} \mathrm{C}$ in humidified air in $150 \mathrm{mmol} / \mathrm{L} \mathrm{NaCl}, 1.5 \mathrm{mmol} / \mathrm{L}$ $\mathrm{CaCl}_{2}$, and $10 \mathrm{mmol} / \mathrm{L}$ Tris- $\mathrm{Cl}(\mathrm{pH} \mathrm{7.4)}$. The pulsating bubble surfactometer was used (23). The bubble radius of $0.40 \mathrm{~mm}$ was maintained for $15 \mathrm{~s}$. Thereafter, the radius was varied between 0.40 and $0.55 \mathrm{~mm}$ at a frequency of $0.33 \mathrm{~Hz}$ for $3 \mathrm{~min}$. The pressure difference $(\Delta P)$ across the surface was continuously recorded. The surface tension at minimum bubble radius was calculated according to the law of Young and LaPlace: $\Delta \mathrm{P}=2 \gamma /$ radius. The rate of surface adsorption was estimated as follows: the bubble (radius $0.4 \mathrm{~mm}$ ) was created and maintained while the decrease of surface tension was continuously recorded until it reached a plateau (i.e. equilibrium surface tension). The rate of surface adsorption illustrates the decrease of surface tension from $70 \mathrm{mN} / \mathrm{m}$ toward equilibrium surface tension.

AS was studied for its components and its capacity to decrease surface activity. The surfactant-rich fraction was isolated by differential sedimentation as described, and the phospholipid concentration of the lyophilized material was adjusted to $2 \mu \mathrm{mol} / \mathrm{mL}$ of $150 \mathrm{mmol} / \mathrm{L} \mathrm{NaCl}$, $1.5 \mathrm{mmol} / \mathrm{L} \mathrm{CaCl}, 10 \mathrm{mmol} / \mathrm{L}$ Tris- $\mathrm{Cl}$ ( $\mathrm{pH} \mathrm{7.4)}$. For the measurement of the surfactant inhibitor, the high-speed supernatant $(40000 \times g$ for $120 \mathrm{~min})$ was further fractioned using a Centricon 3 microconcentrator (cutoff 3 $\mathrm{kD}$; Amicon, Beverly, MA). The protein-rich retentate was lyophilized. The protein was adjusted to a final concentration of 4 or $8 \mathrm{~g} / \mathrm{L}$ : the dry specimen was brought into suspension by adding $150 \mathrm{mmol} / \mathrm{L} \mathrm{NaCl}, 1.5 \mathrm{mmol} / \mathrm{L}$ $\mathrm{CaCl}_{2}, 10 \mathrm{mmol} / \mathrm{L}$ Tris-Cl (pH 7.4). Thereafter, human surfactant isolated from the amniotic fluid (24) was added to a final concentration of 1.8 or $7.2 \mathrm{mmol} P C / L$, and the specimen was incubated for $30 \mathrm{~min}$ at $37^{\circ} \mathrm{C}$ with periodic agitation before measurement of surface activity.

Measurements of $I L-1 \beta, L F$, and MPO. IL-1 $\beta$ was measured using an immunoassay (Quantikine, Research and 
Diagnostics Systems Inc., Minneapolis, MN). RIA for MPO and LF were performed as described (25).

Presentation of results. The concentrations of PC, SPC, SP-A, MPO, LF, IL-1 $\beta$, and nonsedimentable protein in ELF were calculated using urea as a marker of the extracellular space (26). Urea was quantified in serum (recovered within $24 \mathrm{~h}$ from the AS) and in AS using an enzymatic method (19). The concentration of PC was calculated as follows: $[\mathrm{PC}]_{\mathrm{ELF}}=[\mathrm{PC}]_{\mathrm{AS}} \times$ urea $_{\text {serum }} /$ urea ${ }_{\text {As }}$.

The concentrations of surfactant components, MPO, LF, and IL-1 $\beta$ are shown for specimens collected 1 to 2 $\mathrm{d}$ before and 1 to $3 \mathrm{~d}$ after the onset of DEX or PL; surface activities of specimens collected 1 to $2 \mathrm{~d}$ before and 2 to $5 \mathrm{~d}$ after the onset of DEX or PL are also given. For measurements of surface activity and inhibition of surface activity by proteins, specimens from $\mathrm{d} 2$ to 5 were combined to have enough material for testing. Twentyeight specimens from a total of 14 infants were studied for minimum surface tension of the phospholipid complex, and 20 specimens from 10 infants were studied for inhibition of surface activity. Because data are missing owing to extubation of infants, results of specimens collected more than $5 \mathrm{~d}$ after the onset of DEX or PL treatment are not presented.

Statistics. The results are expressed as numbers of infants, means \pm SD or SEM, or medians and quartiles. Two-sided $t$ test, Mann-Whitney $U$ test, analysis of variance, Wilcoxon signed rank-test, and $\chi^{2}$-test with continuity correction were used. A $p$ value of less than 0.05 was considered significant.

\section{RESULTS}

Clinical outcome. Some clinical characteristics of the 23 enrolled infants are presented in Table 1. The treatment was started at the postnatal age of $15 \mathrm{~d}$ in the DEX group and $14 \mathrm{~d}$ in the PL group. There was no significant difference in the ventilatory settings between the groups at entry (Table 2). Three days after entry, DEX-treated infants required significantly less ventilatory support and supplemental oxygen than at entry. Three infants died, one infant in the DEX group (at the age of $125 \mathrm{~d}$ ) and two in the PL group (at the ages of 22 and $28 \mathrm{~d}$ ). During the 1 -wk treatment period, six $(55 \%)$ of the infants in the DEX group and two (17\%) of the infants in the PL group were weaned from the ventilator $(p=0.14)$, but four of the six DEX-treated infants required later reintubation

Table 1. Characteristics of infants /number of infants or mean $(S D)]^{*}$

\begin{tabular}{lcc}
\multicolumn{3}{c}{ mean $(S D)]^{*}$} \\
& $\begin{array}{c}\text { DEX group } \\
(n=11)\end{array}$ & $\begin{array}{c}\text { PL group } \\
(n=12)\end{array}$ \\
\hline Birth weight (g) & $873(223)$ & $803(110)$ \\
Gestational age (wk) & $26.8(1.7)$ & $26.0(1.5)$ \\
Males [ $n(\%)]$ & $8(73 \%)$ & $3(25 \%)$ \\
Postnatal age at start of trial medication (d) & $15(3)$ & $14(3)$ \\
\hline
\end{tabular}

* All comparisons between DEX and PL group were NS.
Table 2. Ventilatory parameters at entry and during treatment period /number of infants or mean $(S D)]^{*}$

\begin{tabular}{|c|c|c|}
\hline & $\begin{array}{c}\text { DEX group } \\
(n=11)\end{array}$ & $\begin{array}{c}\text { PL group } \\
(n=12)\end{array}$ \\
\hline \multicolumn{3}{|l|}{ At entry } \\
\hline Rate of ventilation & $31(18)$ & $33(15)$ \\
\hline Peak inspiratory pressure $\left(\mathrm{cm} \mathrm{H}_{2} \mathrm{O}\right)$ & $20(3)$ & $20(3)$ \\
\hline Mean airway pressure $\left(\mathrm{cm} \mathrm{H}_{2} \mathrm{O}\right)$ & $8.3(2.2)$ & $8.1(2.2)$ \\
\hline $\mathrm{FiO}_{2}^{\dagger}$ & $0.43(0.20)$ & $0.42(0.19)$ \\
\hline $\mathrm{FiO}_{2} \times \mathrm{MAP}$ & $4.1(3.0)$ & $3.5(1.5)$ \\
\hline \multicolumn{3}{|l|}{ After $3 \mathrm{~d}$} \\
\hline Ventilator dependent & 9 & 10 \\
\hline Rate of ventilation & $26(16)$ & $32(19)$ \\
\hline Peak inspiratory pressure $\left(\mathrm{cm} \mathrm{H}_{2} \mathrm{O}\right)$ & $19(3)$ & $20(2)$ \\
\hline Mean airway pressure $\left(\mathrm{cm} \mathrm{H}_{2} \mathrm{O}\right)$ & $6.9(2.3)$ & $7.8(3.0)$ \\
\hline $\mathrm{Fio}_{2}$ & $0.32(0.11) \ddagger$ & $0.39(0.23)$ \\
\hline $\mathrm{FiO}_{2} \times \mathrm{MAP}$ & $2.6(1.6) \ddagger$ & $3.6(3.0)$ \\
\hline
\end{tabular}

* MAP, mean airway pressure; $\mathrm{Fio}_{2}$ fractional inspiratory oxygen. Conversion: $10 \mathrm{~cm} \mathrm{H}_{2} \mathrm{O}=1 \mathrm{kPa}$.

† Mean $\mathrm{FiO}_{2}$ requirement during the $24 \mathrm{~h}$ before start of trial medication ( $\mathrm{Fio}_{2}$ recorded $24,18,12$, and $6 \mathrm{~h}$ before entry).

$\ddagger p<0.05$, comparison of ventilatory parameters at entry and after 3 d. All comparisons between DEX and PL group were NS.

and ventilatory support. Median duration of ventilatory support was similar in both groups (DEX 24.0 d, PL 26.0 $\mathrm{d} ; p=0.78$ ). The survival rate at $28 \mathrm{~d}$ without ventilatory support or CLD did not differ between the groups [survival without ventilatory support: DEX 5/11 (45\%), PL $2 / 12(17 \%), p=0.30$; survival without CLD: DEX 1/11 (9\%), PL 0/12 (0\%), $p=0.96]$.

Nonsedimentable protein. Protein concentrations in ELF at entry were similar in each group ([protein] $]_{\text {ELF }}$ : DEX $13.6 \mathrm{~g} / \mathrm{L}, \mathrm{PL} 9.2 \mathrm{~g} / \mathrm{L}, p=0.48$; Fig. 1). After $3 \mathrm{~d}$, the concentrations of protein were significantly lower in the DEX-treated than in the PL-treated infants ([protein $]_{\text {ELF }}$ : DEX $2.9 \mathrm{~g} / \mathrm{L}$, PL $5.7 \mathrm{~g} / \mathrm{L}, p=0.027$ ). Concentrations of protein in ELF tended to be lower 1 to $2 \mathrm{~d}$ after the onset of DEX or PL (data not shown) and were lower after $3 \mathrm{~d}$ of treatment in the eight infants weaned from the ventilator during the 1 -wk treatment period compared with the 15 infants who were not weaned ([protein $]_{\text {ELF }}$ : weaned $1.5 \mathrm{~g} / \mathrm{L}$, ventilator dependent $4.0 \mathrm{~g} / \mathrm{L}, p=0.024)$. The

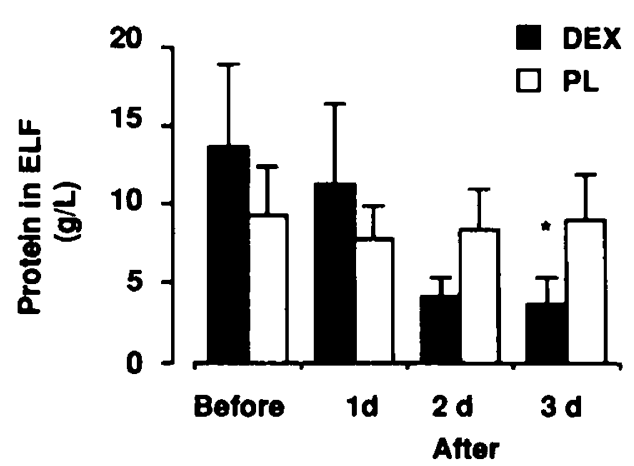

Figure 1. Total nonsedimentable protein in ELF $(g / L)$. AS were collected 1 or $2 \mathrm{~d}$ before and 1 to $3 \mathrm{~d}$ after the onset of DEX or PL (mean and SEM). Number of specimens before entry: DEX, $n=8$; PL, $n=8$; after $1 \mathrm{~d}$ : DEX, $n=10$; PL, $n=7$; after $2 \mathrm{~d}$ : DEX, $n=9$; PL, $n=10$; and after $3 \mathrm{~d}$ : DEX, $n=8$; PL, $n=10 .{ }^{*}, p<0.05$ compared with PL group. 
molecular weight distribution of protein in AS was analyzed using gel electrophoresis. There were 18 specimens from six DEX-treated infants and 27 specimens from six PL-treated infants. According to this analysis, the composition of AS protein remained similar in each group during the treatment period. The molecular weight distribution of AS protein was similar to that of serum protein (data not shown). The ratio [protein $]_{A S}:[\text { protein }]_{\text {serum }}$ did not differ between the groups before the treatment was started [DEX $4.9(n=3)$; PL $5.5(n=5)\left(\mathrm{g} \times \mathrm{L}^{-1}\right) /(\mathrm{g} \times$ $\left.\mathrm{mL}^{-1}\right) ; p=0.73$, but it was lower after 2 to $5 \mathrm{~d}$ in the DEX-treated than in PL-treated infants [DEX $1.0(n=4)$; PL $\left.6.7(n=5)\left(\mathrm{g} \times \mathrm{L}^{-1}\right) /\left(\mathrm{g} \times \mathrm{mL}^{-1}\right) ; p=0.01\right]$.

Surfactant components, surfactant inhibitors, and surface activity of sedimentable surfactant complex. Concentrations of SP-A and PC in ELF before entry into the study and 1 to $3 \mathrm{~d}$ after the onset of treatment with DEX or PL are presented in Table 3 . There was a wide variation in the concentrations of all surfactant components during the 1-wk treatment period. DEX treatment had no significant effect on concentrations of PC in ELF (Table 3) or on concentrations of SPC in ELF (data not shown). There was no significant difference between the groups in the SP-A concentrations at entry (Table 3 ). In the PL-treated infants, SP-A concentrations remained similar during the treatment period, whereas in the DEX-treated infants a transient increase in SP-A levels was evident after $1 \mathrm{~d}$ (Table 3). Thereafter, the SP-A levels of DEX-treated infants decreased and reached the pretreatment levels (Table 3). During the $3 \mathrm{~d}$ after the onset of DEX or PL, concentrations of SP-A, PC, and SPC did not differ significantly between the infants who were weaned from the ventilator during the treatment period compared with those who were not (data not shown).

DEX had no detectable effect on the ratio of SPC/PC. This ratio was similar in both groups at entry (DEX 0.39 $\mathrm{mol} / \mathrm{mol}$ and PL $0.48 \mathrm{~mol} / \mathrm{mol} ; p=0.21$ ) and during the treatment period (after $1 \mathrm{~d}, \mathrm{DEX} 0.46 \mathrm{~mol} / \mathrm{mol}$ and $\mathrm{PL}$ $0.46 \mathrm{~mol} / \mathrm{mol}, p=0.93$; after $2 \mathrm{~d}$, DEX $0.41 \mathrm{~mol} / \mathrm{mol}$ and PL $0.48 \mathrm{~mol} / \mathrm{mol}, p=0.46$; and after $3 \mathrm{~d}$, DEX 0.41 $\mathrm{mol} / \mathrm{mol}$ and $\mathrm{PL} 0.47 \mathrm{~mol} / \mathrm{mol}, p=0.23$ ). Ratios of SP-A/SPC and SP-A/PC before entry into the study and 1 to $3 \mathrm{~d}$ after the onset of the treatment are presented in
Figure 2. At entry, SP-A/SPC and SP-A/PC ratios did not differ between the DEX and PL groups (SP-A/SPC: DEX $62.0 \mathrm{~g} / \mathrm{mol}$, PL $47.5 \mathrm{~g} / \mathrm{mol}, p=0.55$; SP-A/PC: DEX 29.4 $\mathrm{g} / \mathrm{mL}$, PL $19.9 \mathrm{~g} / \mathrm{mol}, p=0.28)$. One day after the onset of DEX, a short-lived increase was noticed in SP-A/SPC and SP-A/PC ratios (SP-A/SPC ratio: DEX $96.9 \mathrm{~g} / \mathrm{mol}$, PL $40.5 \mathrm{~g} / \mathrm{mol}, p=0.037$; SP-A/PC: DEX $35.9 \mathrm{~g} / \mathrm{mol}$, PL $16.1 \mathrm{~g} / \mathrm{mol}, p=0.043)$. Thereafter, both ratios of DEXtreated infants decreased and reached the levels of PLtreated infants. Ratios of SP-A/PC, SP-A/SPC, and SPC/PC during the $3 \mathrm{~d}$ after the onset of DEX or PL were similar in those infants who were weaned from the ventilator during the treatment period and those who were not (data not shown).

Surface activity of the sedimentable lipid-protein complex of AS, before entry and after 2 to $5 \mathrm{~d}$, is presented in Table 4. Minimum surface tension of the sedimentable surfactant complex did not differ significantly between the groups before entry into the study $(p=0.15)$ or after 2 to $5 \mathrm{~d}$ of treatment $(p=0.55)$. There was no difference in the surface adsorption rates (data not shown).

The inhibitory effect of the nonsedimentable protein on surface activity of human surfactant was measured in the AS collected before entry into the study and after 2 to 5 $d$ (Table 4). Before entry, the minimum surface tension of surfactant in the presence of the nonsedimentable protein was similar in both groups $(p=0.69)$. After 2 to $5 \mathrm{~d}$ at a constant concentration, the nonsedimentable protein in AS of DEX-treated infants had a lower inhibitory effect on surface activity of human surfactant in vitro than protein in AS of PL-treated infants $(p=0.047)$. These surfactant inhibitors did not affect the surface adsorption rates (data not shown). Because too few specimens were available for the study, pulmonary outcome and surface tension measurements could not be correlated.

The impact of the total nonsedimentable protein concentration $(4 \mathrm{mg}$ protein $/ \mathrm{mL}$ and $8 \mathrm{mg}$ protein $/ \mathrm{mL}$ ) and the $\mathrm{PC}$ concentration in human surfactant $(1.8 \mathrm{mmol} / \mathrm{L}$ and 7.2 $\mathrm{mmol} / \mathrm{L}$ ) on surface activity were further studied in vitro. The inhibitory effect of the nonsedimentable protein fraction $(4 \mathrm{mg}$ protein $/ \mathrm{mL}$ ) on surfactant function disappeared when the concentration of PC in human surfactant was increased from $1.8 \mathrm{mmol} / \mathrm{L}$ to $7.2 \mathrm{mmol} / \mathrm{L}$ (minimum sur-

Table 3. $S P$ - $A$ and $P C$ in $E L F^{*}$

\begin{tabular}{|c|c|c|c|c|c|c|c|c|}
\hline & \multicolumn{4}{|c|}{ DEX group } & \multicolumn{4}{|c|}{ PL group } \\
\hline & \multirow[b]{2}{*}{ Before } & \multicolumn{3}{|c|}{ After } & \multirow[b]{2}{*}{ Before } & \multicolumn{3}{|c|}{ After } \\
\hline & & $1 \mathrm{~d}$ & $2 \mathrm{~d}$ & $3 \mathrm{~d}$ & & $1 \mathrm{~d}$ & $2 \mathrm{~d}$ & $3 d$ \\
\hline \multicolumn{9}{|c|}{$[\mathrm{SP}-\mathrm{A}]_{\mathrm{ELF}}(\mathrm{mg} / \mathrm{L})$} \\
\hline Median & 51 & 240 & 133 & $63 \dagger$ & 118 & 121 & 95 & 83 \\
\hline Quartile & $27-133$ & $151-365$ & $41-210$ & $24-147$ & $31-144$ & $66-237$ & $66-135$ & $66-144$ \\
\hline $\begin{array}{l}\text { No. AS } \\
{[\mathrm{PC}]_{\text {ELF }}(\mathrm{m}}\end{array}$ & $n=6$ & $n=8$ & $n=7$ & $n=8$ & $n=7$ & $n=6$ & $n=9$ & $n=9$ \\
\hline Median & 3.1 & 6.1 & 5.9 & 3.8 & 7.6 & 3.7 & 6.5 & 6.6 \\
\hline Quartile & $2.4-4.1$ & $2.3-10.7$ & $3.7-7.5$ & $2.2-5.2$ & $4.5-14.0$ & $3.4-14.7$ & $3.8-10.1$ & $4.0-8.3$ \\
\hline No. AS & $n=6$ & $n=8$ & $n=7$ & $n=8$ & $n=8$ & $n=7$ & $n=8$ & $n=8$ \\
\hline
\end{tabular}

* Specimens were collected 1 to $2 \mathrm{~d}$ before and 1 to $3 \mathrm{~d}$ after onset of DEX or PL treatment.

$\dagger p<0.05$ compared with specimens collected $1 \mathrm{~d}$ after onset of DEX treatment. All other comparisons were NS. 

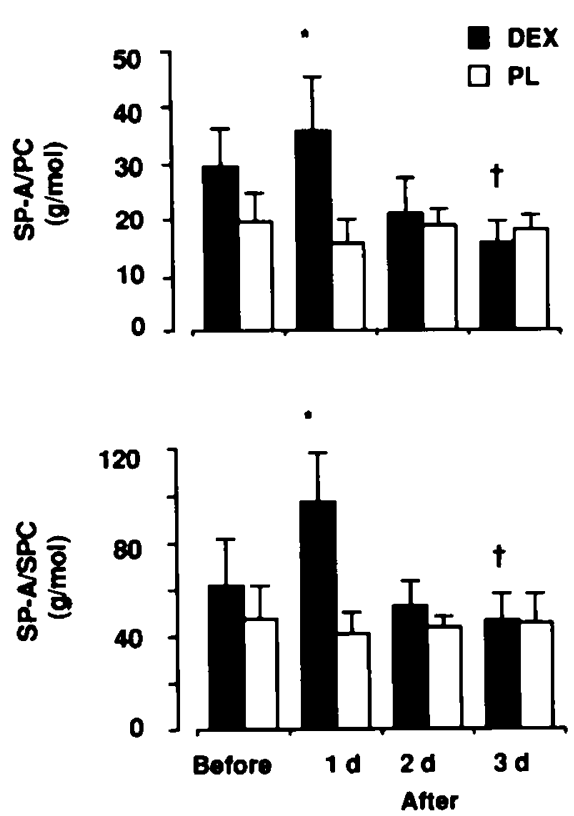

Figure 2. Ratio of SP-A to PC (g/mol) (upper panel) and ratio of SP-A to SPC $(\mathrm{g} / \mathrm{mol})$ (lower panel) in AS. AS were collected 1 or $2 \mathrm{~d}$ before and 1 to $3 \mathrm{~d}$ after the onset of DEX or PL (mean and SEM). Number of specimens for SP-A/PC before entry: DEX, $n=7$; PL, $n=9$; after $1 \mathrm{~d}$ : DEX, $n=9$; PL, $n=8$; after 2 d: DEX, $n=7$; PL, $n=9$; and after 3 d: DEX, $n=8$; PL, $n=9$. Number of specimens for SP-A/SPC before entry: DEX, $n=4$; PL, $n=6$; after $1 \mathrm{~d}$ : DEX, $n=8$; PL, $n=7$; after $2 \mathrm{~d}$ : DEX, $n=6$; PL, $n=8$; and after $3 \mathrm{~d}$ : DEX, $n=6$; PL, $n=7$. $^{*}$, $p<0.05$ compared with PL group; $\dagger, p<0.05$ compared with $d-1$ value in DEX group.

face tension of surfactant: $2 \mathrm{mN} / \mathrm{m}$; minimum surface tension of surfactant + inhibitor: $3 \mathrm{mN} / \mathrm{m} ; p=0.46, n=5$ ). However, a higher concentration of nonsedimentable fraction $(8 \mathrm{mg}$ protein $/ \mathrm{mL}$ ) signficantly increased the minimum surface tension of human surfactant, containing 7.2 $\mathrm{mmol} / \mathrm{L}$ PC (minimum surface tension of surfactant: 2 $\mathrm{mN} / \mathrm{m}$; minimum surface tension of surfactant + inhibitor: $9 \mathrm{mN} / \mathrm{m} ; p=0.02, n=4)$; the protein fraction from DEX-treated infants tended to be less inhibitory than the

Table 4. Surface activity of sedimentable lipid-protein complex in AS and inhibitory effect of nonsedimentable protein on surface activity of human surfactant /mean (SD) or number of specimen $]^{*}$

\begin{tabular}{lcc}
\hline & DEX group & PL group \\
\hline $\begin{array}{l}\text { Minimum surface tension of } \\
\text { lipid-protein complex }(\mathrm{mN} / \mathrm{m})\end{array}$ & $n=7$ & $n=7$ \\
$\quad$ Before & $19.8(1.7)$ & $16.3(5.7)$ \\
$\quad$ After 2 to $5 \mathrm{~d}$ & $17.6(2.2)$ & $15.8(7.6)$ \\
Minimum surface tension of & $n=5$ & $n=5$ \\
human surfactant in presence of & & \\
nonsedimentable protein $(\mathrm{mN} / \mathrm{m}) \dagger$ & & \\
$\quad$ Before & $16.2(5.9)$ & $17.4(1.6)$ \\
$\quad$ After 2 to $5 \mathrm{~d}$ & $12.7(4.6)$ & $17.7(1.4) \ddagger$ \\
\hline
\end{tabular}

\footnotetext{
* Specimens were collected 1 to $2 \mathrm{~d}$ before and 2 to $5 \mathrm{~d}$ after onset of DEX or PL treatment.

† The final concentration of protein in the nonsedimentable fraction of AS was $4 \mathrm{~g} / \mathrm{L}$, and the final concentration of surfactant PC was 1.8 $\mathrm{mmol} / \mathrm{L}$. The minimum surface tension of human surfactant without inhibitor was $3.9(0.7) \mathrm{mN} / \mathrm{m}$.

$\ddagger p<0.05$ compared with DEX group.
}

fraction from PL-treated infants (after 2 to $5 \mathrm{~d}$ DEX, 3 and $8 \mathrm{mN} / \mathrm{m}$; after 2 to $5 \mathrm{~d} \mathrm{PL}, 9$ and $15 \mathrm{mN} / \mathrm{m}$ ).

Inflammatory mediators: IL-1B, MPO, and LF. At entry and during the treatment period, MPO and LF concentrations in ELF did not differ significantly in DEX- or PL-treated infants (Table 5). IL-1 $\beta$ concentrations were also similar in both groups at entry and during the treatment period (Table 5).

\section{DISCUSSION}

According to current evidence, DEX treatment of preterm ventilator-dependent infants with threatened CLD decreases the requirements of ventilatory support $(3,5$, $7,8,16,18)$ and improves pulmonary mechanics (4-6). DEX treatment has decreased the concentrations of albumin in lung effluent $(5,15,16)$, suggesting decreased endothelial and epithelial permeability. Increased epithelial permeability has been detected in preterm infants with respiratory distress syndrome, and this abnormal permeability persists in infants subsequently developing CLD (27). In the present study, DEX treatment decreased the concentrations of nonsedimentable protein in ELF and also decreased the ratio of protein in AS to protein in serum. The nonsedimentable protein fraction of AS disturbed the ability of the pulmonary surfactant to reach very low surface tension in vitro. The inhibition of surfactant function was dependent on both the inhibitor and surfactant concentrations. The inhibition of surface activity was detectable when the concentration of surfactant PC and nonsedimentable protein were within ranges that were evident in ELF of most infants (Fig. 1, Table 3). The minimum surface tensions obtained in the present study were high. However, these patients were critically ill, small, preterm infants who may have had abnormal surfactant function. We measured lower minimum surface tensions when the humidity of ambient air was decreased. Because the humidity of alveolar air is $100 \%$, we chose to report the measurements close to $100 \%$ humidity. In a few cases when sufficient quantities of AS were available, the surface tension was confirmed using a modified Wilhelmy balance (28).

In addition to decreasing concentration of protein in ELF, DEX treatment weakened the properties of the nonsedimentable protein as an inhibitor of surfactant function. The cause of the DEX-induced decrease in surfactant inhibitor activity is unknown. Less than $10 \%$ of phospholipid or SP-A was recovered in the nonsedimentable fraction of AS, regardless of the treatment. There was no detectable difference between the DEX and PL groups in the molecular weight distribution of the proteins from the nonsedimentable fraction. The molecular weight distribution of the protein in AS was similar to that of serum protein. However, the present method of gel electrophoresis does not detect small differences in protein composition that may account for the observed difference in the inhibitor potency. 
KARI $E T A L$.

Table 5. Inflammatory parameters in $E L F^{*}$

\begin{tabular}{|c|c|c|c|c|c|c|c|c|}
\hline & \multicolumn{4}{|c|}{ DEX group } & \multicolumn{4}{|c|}{ PL group } \\
\hline & \multirow[b]{2}{*}{ Before } & \multicolumn{3}{|c|}{ After } & \multirow[b]{2}{*}{ Before } & \multicolumn{3}{|c|}{ After } \\
\hline & & $1 \mathrm{~d}$ & $2 \mathrm{~d}$ & $3 \mathrm{~d}$ & & $1 d$ & $2 \mathrm{~d}$ & $3 \mathrm{~d}$ \\
\hline \multicolumn{9}{|c|}{$[\mathrm{LF}]_{\mathrm{ELF}}(\mathrm{mg} / \mathrm{L})$} \\
\hline Median & 71 & 78 & 99 & 97 & 96 & 113 & 89 & 119 \\
\hline Quartile & $38-115$ & $46-96$ & $32-219$ & $37-195$ & $64-126$ & $17-208$ & $67-126$ & $38-282$ \\
\hline No. AS & $n=7$ & $n=5$ & $n=8$ & $n=8$ & $n=8$ & $n=2$ & $n=9$ & $n=7$ \\
\hline \multicolumn{9}{|c|}{$[\mathrm{IL}-1 \beta]_{\text {ELF }}(\mathrm{mg} / \mathrm{L})$} \\
\hline Median & 2.2 & 2.2 & 0.7 & 1.2 & 2.1 & 0.8 & 1.0 & 1.0 \\
\hline Quartile & $0.1-3.0$ & $1.3-14.9$ & $0.1-1.5$ & $0.9-4.6$ & $0.9-12.5$ & $0.5-1.7$ & $0.6-1.5$ & $0.8-1.3$ \\
\hline No. AS & $n=5$ & $n=7$ & $n=6$ & $n=7$ & $n=7$ & $n=6$ & $n=9$ & $n=8$ \\
\hline \multicolumn{9}{|c|}{$[\mathrm{MPO}]_{\mathrm{ELF}}(\mathrm{mg} / \mathrm{L})$} \\
\hline Median & 118 & 51 & 54 & 47 & 81 & 28 & 40 & 76 \\
\hline Quartile & $68-147$ & $29-71$ & $30-121$ & $25-67$ & $52-121$ & $11-45$ & $24-75$ & $27-214$ \\
\hline No. AS & $n=7$ & $n=5$ & $n=8$ & $n=8$ & $n=8$ & $n=2$ & $n=9$ & $n=7$ \\
\hline
\end{tabular}

* Specimens were collected 1 to $2 \mathrm{~d}$ before and 1 to $3 \mathrm{~d}$ after onset of DEX or PL treatment. All comparisons were NS.

The decrease of protein concentration in ELF during DEX treatment could be due to several mechanisms. Glucocorticoid treatment has been shown to decrease microvascular permeability (29), increase the epithelial clearance of macromolecules (30), and decrease neutrophil recruitment $(5,16)$, resulting in lung edema $(5,16,29)$. In ventilated preterm rabbits, prenatal steroid treatment decreased protein leak across capillary endothelium and increased clearance of protein from the bronchoalveolar lavage (30). It has been suggested that the favorable effect of prenatal steroid treatment in ventilated animals is primarily mediated through pulmonary maturation and not through a direct pharmacologic effect (30). Steroids may have a somewhat different mechanism of action in CLD or early CLD from that detected in prenatal treatment. Several studies have failed to show a sustained beneficial effect of DEX in preterm infants when the treatment was discontinued $(3,5,18)$. It has been speculated that respiratory failure seen after discontinuation of DEX is related to the return of the inflammatory state (5). The results of the present study are consistent with the possibility that DEX increases the clearance of plasma-derived proteins from ELF or decreases the flux of plasma-derived proteins into the alveolar space.

In the present study, DEX treatment had no detectable effect on the concentrations of PC or SPC in ELF. Prenatal steroid treatment of rabbits has increased phospholipids in alveolar lavage at preterm birth, but after ventilation the size of the alveolar surfactant pool has been similar in both steroid-treated and control rabbits (30-33). Prenatal steroid treatment has not increased the phospholipid concentrations in amniotic fluid or in gastric aspirates of the newborn infants at birth (34). Our results and results of previous animal studies suggest that postnatal glucocorticoid treatment of ventilator-dependent preterm infants has no clearcut effect on the concentrations of alveolar phospholipids.

One day after the onset of DEX, the SP-A/SPC ratios and the SP-A/PC ratios were significantly higher compared with the corresponding ratios in other specimens from DEX- and PL-treated infants. Thus, the increase in SP-A/SPC ratio corresponded with a transient increase in the concentration of SP-A in ELF. According to studies using lung explants, glucocorticoid transiently stimulates the synthesis of the mRNA for SP-A (35). SP-A has been shown to be protective against surfactant inhibition caused by specific proteins and amino acids $(19,36)$ and to delay conversion of the large surfactant aggregates toward the small aggregates that are no longer surface active (37). Moreover, the increase in SP-A may transiently improve the host-defense mechanism of alveolar macrophages (38). The present results do not exclude the possibility that DEX increased the concentrations of surfactant protein-B (39) or surfactant protein-C (40), both of which increase surface activity. In any case, we were unable to detect any qualitative differences between DEX- and PL-treated infants in surface activity of the lipid-protein complex isolated from AS.

DEX treatment started at $d 14$ had no detectable effect on IL-1 $\beta$ concentrations in ELF. The MPO and LF levels were also similar in each group. The IL-1 $\beta$ levels in this study were of similar magnitude to those detected in preterm infants evolving CLD $(41,42)$. In contrast to our results, Groneck et al. (16) found a decrease in the IL-1 $\beta$ concentrations in tracheobronchial fluid of the preterm ventilator-dependent infants during early DEX treatment starting at $10 \mathrm{~d}$ of age but not when DEX treatment was started at $16 \mathrm{~d}$ of age. IL-1 $\beta$ levels tended to be lower in their early treatment group, both before and during the DEX treatment, than in this study (16). High activity of MPO in bronchoalveolar lavage fluid has been associated with lung injury in adults (43). Low levels of LF, an iron-binding protein found in neutrophils and serous cells of airway submucosal glands, are related to immaturity and to development of CLD in preterm infants (44). It has been proposed that high LF levels may reflect protective capacity of the lungs against injury (44). The reason why we did not find any effect of DEX on inflammatory mediators or on LF is unclear. In experimental studies, glucocorticoids suppress inflammation (29) and down- 
regulate cytokines (45). Severity of lung injury, timing, dose, and duration of the DEX treatment in this study may explain the failure to detect any effect of DEX on MPO and IL-1 $\beta$ levels.

In the present study, DEX treatment decreased significantly the concentrations of protein in ELF and decreased the ratio of protein in AS to serum protein, suggesting decreased capillary permeability, increased epithelial clearance of protein, or both. The decrease in the protein concentration of ELF coincided with the decrease in the capacity of this protein to decrease the surface activity. We propose that the acute favorable effect of DEX in CLD and in infants at risk for CLD is in part mediated through improvement of surfactant function: low interfacial surface tension may thus contribute toward clearance of lung edema fluid and increase lung compliance after glucocorticoid treatment.

Acknowledgments. The authors thank Dr. T. Akino for providing the kit for the SP-A assay, Dr. S. Andersson for advice and help in measurements of inflammatory parameters, and the Organon Company for providing the DEX and PL ampules.

\section{REFERENCES}

1. O'Brodovich HM, Mellins RB 1985 Bronchopulmonary dysplasia: unresolved neonatal acute lung injury. Am Rev Respir Dis 132:694-709

2. deLemos RA, Coalson JJ 1992 The contribution of experimental models to our understanding of the pathogenesis and treatment of bronchopulmonary dysplasia. Clin Perinatol 19:521-539

3. Mammel MC, Green TP, Johnson DE. Thompson TR 1983 Controlled trial of dexamethasone therapy in infants with bronchopulmonary dysplasia. Lancet $1: 1356-1358$

4. Avery GB, Fletcher AB, Kaplan M, Brudno DS 1985 Controlled trial of dexamethasone in respirator-dependent infants with bronchopulmonary dysplasia. Pediatrics 75:106-111

5. Yoder MC, Chua R, Tepper R 1991 Effect of dexamethasone on pulmonary inflammation and pulmonary function of ventilator-dependent infants with bronchopulmonary dysplasia. Am Rev Respir Dis 143:1044-1048

6. Gladstone IM, Ehrenkranz RA, Jacobs HC 1989 Pulmonary function tests and fluid balance in neonates with chronic lung disease during dexamethasone treatment. Pediatrics 84:1072-1076

7. Cummings JJ, D'Eugenio DB, Gross SJ 1989 A controlled trial of dexameth asone in preterm infants at high risk for bronchopulmonary dysplasia. $\mathrm{N}$ Eng J Med 320:1505-1510

8. Harkavy KL, Scanlon JW, Chowdhry PK, Grylack LJ 1989 Dexamethasone therapy for chronic lung disease in ventilator- and oxygen-dependent infants: a controlled trial. J Pediatr 115:979-983

9. Kazzi NJ, Brans YW, Poland RL 1990 Dexamethasone effects on the hospital course of infants with bronchopulmonary dysplasia who are dependent on artificial ventilation. Pediatrics 86:722-727

10. Collaborative Dexamethasone Trial Group 1991 Dexamethasone therapy in neonatal chronic lung disease: an international placebo-controlled trial. Pediatrics 88:421-427

11. Ohlsson A, Calvert SA, Hosking M, Shennan AT 1992 Randomized controlled trial of dexamethasone treatment in very-low-birth-weight infants with ventilator-dependent chronic lung disease. Acta Paediatr 81:751-756

12. deLemos RA, Shermeta DW, Knelson JH, Kotas R, Avery ME 1970 Acceleration of appearance of pulmonary surfactant in the fetal lamb by adminis tration of corticosteroids. Am Rev Respir Dis 102:459-461

13. Post M, Smith BT 1992 Hormonal control of surfactant metabolism. In Robertson B, Van Golde LMG, Batenburg JJ (eds) Pulmonary Surfactant from Molecular Biology to Clinical Practice. Elsevier, Amsterdam, pp 379 424

14. Frank L, Lewis PL, Sosenko IRS 1985 Dexamethasone stimulation of fetal rat lung antioxidant enzyme activity in parallel with surfactant stimulation. Pediatrics 75:569-574

15. Watts CL, Bruce MC 1992 Effect of dexamethasone therapy on fibronectin and albumin levels in lung secretions of infants with bronchopulmonary dysplasia. J Pediatr 121:597-607

16. Groneck P, Reuss D, Götze-Speer B, Speer CP 1993 Effects of dexamethasone on chemotactic activity and inflammatory mediators in tracheobronchia aspirates of preterm infants at risk for chronic lung disease. J Pediatr 122:938944

17. Gerdes JS, Harris MC, Polin RA 1988 Effects of dexamethasone and indomethacin on elastase, alpha $a_{1}$-proteinase inhibitor, and fibronectin in bronchoalveolar lavage fluid from neonates. J Pediatr 113:727-731

18. Kari MA, Heinonen K, Ikonen RS, Koivisto M, Raivio KO 1993 Dexamethasone treatment in preterm infants at risk for bronchopulmonary dysplasia. Arch Dis Child 68:566-569

19. Hallman M, Merritt TA, Akino T, Bry K 1991 Surfactant protein A, phosphatidylcholine, and surfactant inhibitors in epithelial lining fluid: correlation with surface activity, severity of respiratory distress syndrome, and outcome in small preterm infants. Am Rev Respir Dis 144:1376-1384

20. Kuroki Y, Takahashi H, Fukada Y, Mikawa M, Inagawa A, Fujimoto S, Akino T 1985 Two-site "simultaneous" immunoassay with monoclonal antibodies for the determination of surfactant apoproteins in human amniotic fluid. Pediatr Res 19:1017-1020

21. Hallman M, Arjomaa P, Hoppu K, Teramo K, Akino T 1989 Surfactant proteins in the diagnosis of fetal lung maturity. II: The $35 \mathrm{kd}$ protein and phospholipids in complicated pregnancy. Am J Obstet Gynecol 161:965-999

22. Peterson GL 1977 A simplification of the protein assay method of Lowry et al., which is more generally applicable. Anal Biochem 83:346-356

23. Enhörning G 1977 Pulsating bubble technique for evaluating pulmonary surfactant. J Appl Physiol 43:198-203

24. Hallman M, Merritt TA, Schneider H, Epstein BL, Mannino F, Edwards DK, Gluck L 1983 Isolation of human surfactant from amniotic fluid and a pilot study of its efficacy in respiratory distress syndrome. Pediatrics 71:473-482

25. Olofsson T, Olsson I, Venge P, Elgefors B 1977 Serum myeloperoxidase and lactoferrin in neutropenia. Scand J Haematol 18:73-80

26. Rennard SI, Basset G, Lecossier D, O’Donnell KM, Pinkston P, Martin PG, Crystal RG 1986 Estimation of volume of epithelial lining fluid recovered by lavage using urea as a marker of dilution. J Appl Physiol 60:532-538

27. Jefferies AL, Coates G, O'Brodovich H 1984 Pulmonary epithelial permeability in hyaline-membrane disease. N Engl J Med 311:1075-1080

28. Possmayer F 1992 Biophysical activities of pulmonary surfactant. In: Polin RA, Fox WW (eds) Fetal and Neonatal Physiology. Saunders, Philadelphia, pp 949-962

29. Williams TJ, Yarwood H 1990 Effect of glucocorticoids on microvascular permeability. Am Rev Respir Dis 141:S39-S43

30. Ikegami M, Berry D, ElKady T, Pettenazzo A, Seidner S, Jobe A 1987 Corticosteroids and surfactant change lung function and protein leaks in the lungs of ventilated premature rabbits. J Clin Invest 79:1371-1378

31. Fiascone JM, Jacobs HC, Moya FR, Mercurio MR, Lima DM 1987 Betamethasone increases pulmonary compliance in part by surfactantindependent mechanisms in preterm rabbits. Pediatr Res 22:730-735

32. Seidner S, Rider E, Jobe A, Yamada T, Ikegami M 1992 Effects of antenatal thyrotropin-releasing hormone, antenatal corticosteroids, and postnatal ventilation on surfactant mobilization in premature rabbits. Am J Obstet Gynecol 166:1551-1559

33. Anceschi MM, Petrelli A, Zaccardo G, Barbati A, Di Renzo GC, Cosmi EV, Hallman M 1988 Inositol and glucocorticoid in the development of lung stability in male and female rabbit fetuses. Pediatr Res 24:617-621

34. Farrell PM, Engle MJ, Zachman RD, Curet LB, Morrison JC, Rao AV, Poole WK 1983 Amniotic fluid phospholipids after maternal administration of dexamethasone. Am J Obstet Gynecol 145:484-49()

35. Liley HG, White RT, Benson BJ, Ballard PL 1988 Glucocorticoids both stimulate and inhibit production of pulmonary surfactant protein $A$ in fetal human lung. Proc Natl Acad Sci USA 85:9096-9100

36. Cockshutt AM, Weitz J, Possmayer F 1990 Pulmonary surfactant-associated protein $A$ enhances the surface activity of lipid extract surfactant and reverses inhibition by blood proteins in vitro. Biochemistry 29:8424-8429

37. Ikegami M, Ueda T, Absolom D, Baxter C, Rider E, Jobe A 1993 Improvements in exogenous surfactant function in ventilated preterm lamb lungs. Pediatr Res 33:329A(abstr)

38. Van Iwaarden F, Welmers B, Verhoef J, Haagsman HP, van Golde LMG 1990 Pulmonary surfactant protein A enhances host-defense mechanism of rat alveolar macrophages. Am J Respir Cell Mol Biol 2:91-98

39. O'Reilly MA, Clark JC, Whitsett JA 1991 Glucocorticoid enhances pulmonary surfactant protein B gene transcription. Am J Physiol 260:L37-L43

40. Veletza SV, Nichols KV, Gross I, Lu H, Dynia DW, Floros J 1992 Surfactant protein C: hormonal control of SP-C mRNA levels in vitro. Am J Physiol 262:L684-L687

41. Hallman M, Bry K 1993 Interleukin-18, interleukin receptor antagonist in airway specimens of infants with RDS. Pediatr Res 33:327A(abstr)

42. Watterberg KL, Demers LM, Murphy S 1993 Tracheal interleukin-1 in neonates who develop bronchopulmonary dysplasia. Pediatr Res 33:349A(abstr)

43. Weiland JE, Davis WB, Holter JF, Mohammed JR, Dorinsky PM, Gadek JE 1986 Lung neutrophils in the adult respiratory distress syndrome: clinical and pathophysiologic significance. Am Rev Respir Dis 133:218-225

44. Revenis ME, Kaliner MA 1992 Lactoferrin and lysozyme deficiency in airway secretions: association with the development of bronchopulmonary dysplasia. J Pediatr 121:262-270

45. Bochner BS, Rutledge BK, Schleimer RP 1987 Interleukin 1 production by human lung tissue. II: Inhibition by anti-inflammatory steroids. J Immunol $139: 2303-2307$ 